\title{
Glosa do wyroku Sądu Apelacyjnego w Lublinie z dnia 14 maja 2013 r. III AUa 306/13
}

1.

Stan faktyczny sprawy, na tle której Sąd Apelacyjny w Lublinie wydał glosowany wyrok, nie był szczególnie skomplikowany. M.O. była współwłaścicielką gospodarstwa rolnego (wraz z mężem) i z tego tytułu podlegała ubezpieczeniu społecznemu rolników. 13 czerwca 2011 r. do organu rentowego wpłynęła informacja od Zakładu Ubezpieczeń Społecznych, z treści której wynikało, że M.O. przez kilka lat wykonywała czynności wynikające z umowy agencyjnej i z tego tytułu podlegała obowiązkowym ubezpieczeniom emerytalno-rentowym $\mathrm{w}$ ramach systemu ubezpieczeniowego powszechnego. Decyzją z dnia 27 kwietnia 2012 r. Prezes Kasy Rolniczego Ubezpieczenia Społecznego stwierdził ustanie ubezpieczenia społecznego rolników M.O. w okresie 1 października 1999 r. - 30 września 2004 r. z uwagi na zatrudnienie poza rolnictwem. Od decyzji tej nie zostało złożone odwołanie. 
Kolejną decyzją, również z 27 kwietnia 2012 r., organ rentowy stwierdził nadpłatę składek na ubezpieczenie społeczne rolników, natomiast decyzją z dnia 1 sierpnia 2012 r. odmówił zwrotu części nadpłaty składek z uwagi na to, że od ich opłacenia upłynęło 5 lat i uległy one przedawnieniu.

\section{2.}

Stanowisko organu rentowego uznał za słuszne Sąd Okręgowy w Lublinie, wg którego z art. 41b ust. 11 ustawy z 20 grudnia 1990 r. o ubezpieczeniu społecznym rolników ${ }^{1}$ wynika wprost, że nadpłacone lub nienależnie opłacone składki nie podlegają zwrotowi, jeżeli od dnia ich opłacenia upłynęło 5 lat. Według Sądu Okręgowego w dacie, gdy organ rentowy poinformował o istnieniu nadpłaty, nie było już możliwe domaganie się jej zwrotu.

Odmienny pogląd wyraził Sąd Apelacyjny. Przyjął, że ustawa o ubezpieczeniu społecznym rolników nie zawiera pełnej regulacji w zakresie zwrotu nienależnie opłaconych składek, w związku z czym należy zastosować przepisy ustawy z 13 października 1998 r. o systemie ubezpieczeń społecznych ${ }^{2}$, a dokładniej - art. 24 ust. 6g, według którego nienależnie opłacone składki ulegają przedawnieniu po upływie 5 lat, licząc od dnia:

1. otrzymania z Zakładu Ubezpieczeń Społecznych zawiadomienia o kwocie nienależnie opłaconych składek,

2. opłacenia składek (w przypadku braku zawiadomienia z Zakładu Ubezpieczeń Społecznych).

Czy stanowisko Sądu Apelacyjnego, wg którego ustawa o ubezpieczeniu społecznym rolników nie zawiera pełnej regulacji zwrotu nienależnie opłaconych składek i należy zastosować przepisy ustawy o systemie ubezpieczeń społecznych, jest trafne? 


\section{3.}

Art. 41b ust. 10 ustawy o ubezpieczeniu społecznym rolników reguluje zagadnienie nadpłaconych lub nienależnie opłaconych składek ${ }^{3}$, stanowiąc, że podlegają one z urzędu zaliczeniu na poczet zaległych lub bieżących składek, a w razie ich braku - na poczet przyszłych składek, chyba że płatnik złoży wniosek o zwrot składek. Istotne ograniczenie w zakresie zwrotu składek sformułowano we wspomnianym już art. 41b ust. 11, zgodnie z którym nadpłacone lub nienależnie opłacone składki nie podlegają zwrotowi, jeżeli od dnia ich opłacenia upłynęło 5 lat.

W stanie faktycznym, na tle którego wydano glosowane orzeczenie, nadpłata składek powstała jako konsekwencja wyłączenia M.O. z ubezpieczenia społecznego rolników. Decyzja o wyłączeniu z ubezpieczenia społecznego rolników dotyczyła okresu 1999-2004. Przyjęcie, że okres 5 lat jest liczony tylko od dnia opłacenia składek, jak stanowią przepisy ustawy o ubezpieczeniu społecznym rolników, skutkowałoby w wielu przypadkach uniemożliwieniem ubiegania się o zwrot składek. Na ten problem ${ }^{4}$ zwrócił uwagę Trybunał Konstytucyjny w wyroku z 26 maja 2010 r. ${ }^{5}$ Według TK „rozpoczęcie biegu terminu dochodzenia zwrotu nienależnie opłaconej składki na chwilę «daty ich opłacenia» prowadzi do negatywnego zróżnicowania kategorii płatników, w których przypadku ustalenie, że składka była nienależnie opłacona, następuje w pewien czas po opłaceniu składki. Data opłacenia składki może nie pokrywać się w czasie z datą ustalenia, że składka była nienależnie opłacona”. Trybunał Konstytucyjny wskazał również, że w wypadku, gdy między datą opłacenia składki a datą stwierdzenia braku podstawy do opłacania składek

3 O nadpłacie składek (na ubezpieczenia społeczne regulowane przez ustawę o systemie ubezpieczeń społecznych) zob. szerzej: J. Wantoch-Rekowski, Składki na ubezpieczenie emerytalne. Konstrukcja i charakter prawny, Toruń 2005, s. 175-179; M. Łabanowski [w:] J. Wantoch-Rekowski (red.), Ustawa o systemie ubezpieczeń społecznych. Komentarz, Toruń-Warszawa 2007, s. 203-207.

4 Trybunał analizował konstytucyjność przepisów o zwrocie nadpłaty na gruncie ustawy o systemie ubezpieczeń społecznych (w wersji już nie obowiązującej), jednak jego rozważania są aktualne również $\mathrm{w}$ odniesieniu do składek na ubezpieczenie społeczne rolników.

5 P 29/08, LEX nr 578127. 
upłynie co najmniej 5 lat, to nie istniałaby możliwość zwrotu nienależnie opłaconej składki.

\section{4.}

O ile obowiązująca ustawa o ubezpieczeniu społecznym rolników jest dla płatników w zakresie zwrotu nadpłaconych składek niekorzystna, o tyle ustawa o systemie ubezpieczeń społecznych przewiduje, że nienależnie opłacone składki ulegają przedawnieniu po upływie 5 lat, licząc od daty opłacenia składek lub od daty otrzymania z Zakładu Ubezpieczeń Społecznych zawiadomienia o kwocie nienależnie opłaconych składek. Rozwiązanie przyjęte przez ustawę o systemie ubezpieczeń społecznych jest niewątpliwie zasadne. Byłoby racjonalne, gdyby identyczne rozwiązanie funkcjonowało w odniesieniu do składek na ubezpieczenie społeczne rolników. Słusznie wskazał Sąd Apelacyjny w Lublinie, że art. 52 ust. 1 ustawy o ubezpieczeniu społecznym rolników stanowi, że w sprawach nieuregulowanych $\mathrm{w}$ ustawie stosuje się odpowiednio przepisy ustawy o systemie ubezpieczeń społecznych.

Jest bezsporne, że sytuacji, w której między datą opłacenia składki a datą stwierdzenia braku podstawy do opłacania składek upłynie co najmniej 5 lat, ustawa o ubezpieczeniu społecznym rolników nie przewiduje. Należy zatem „odpowiednio” zastosować - art. 24 ust. 6g pkt 1 ustawy o systemie ubezpieczeń społecznych, tzn. nienależnie opłacone składki ulegają przedawnieniu po upływie 5 lat, licząc od dnia otrzymania od Prezesa Kasy Rolniczego Ubezpieczenia Społecznego zawiadomienia o kwocie nienależnie opłaconych składek. Za „zawiadomienie” uznać można decyzję Prezesa Kasy Rolniczego Ubezpieczenia Społecznego o stwierdzeniu nadpłaty, która może być konsekwencją decyzji o wyłączeniu/o ustaniu rolniczego ubezpieczenia społecznego. 


\section{5.}

Należy podkreślić, że ustawa z 20 grudnia 1990 r. o ubezpieczeniu społecznym rolników problematyki składek na ubezpieczenie społeczne rolników nie reguluje kompleksowo ${ }^{6}$. Art. 52 ust. 1 (in principio) wprost stanowi, że w sprawach nieuregulowanych w ustawie stosuje się odpowiednio przepisy ustawy o systemie ubezpieczeń społecznych. W zakresie zwrotu nadpłaconych lub nienależnie opłaconych składek ustawa o ubezpieczeniu społecznym rolników nie jest „kompletna”. Brak w ustawie o ubezpieczeniu społecznym rolników regulacji, wg której nadpłacone lub nienależnie opłacone składki przedawniają się po 5 latach, licząc od dnia otrzymania z Kasy Rolniczego Ubezpieczenia Społecznego zawiadomienia o kwocie nienależnie opłaconych składek, traktować należy jako „sprawę nieuregulowaną” i zastosować odpowiednio art. 24 ust. 6g pkt 1 ustawy o systemie ubezpieczeń społecznych. Inna interpretacja prowadziłaby do negatywnego zróżnicowania kategorii płatników, co jest - na co wskazał cytowany wyżej TK - niedopuszczalne.

Warto zwrócić uwagę, że w praktyce dochodzi do zbiegu tytułów ubezpieczeń - rolniczego i powszechnego. W związku z tym, że ubezpieczenie społeczne rolników administrowane jest przez Kasę Rolniczego Ubezpieczenia Społecznego, a powszechne - przez Zakład Ubezpieczeń Społecznych, wcale nie incydentalnie zdarzają się przypadki podlegania przez ubezpieczonego równocześnie ubezpieczeniu powszechnemu i rolniczemu. Stan faktyczny, który legł u podstaw wydania glosowanego wyroku, wskazuje, że nawet po wielu latach wydawane są decyzje wyłączające ubezpieczonego z ubezpieczenia rolniczego wobec pozostawania przez niego w systemie powszechnym. Uzasadnione jest więc również ustalanie terminu przedawnienia zwrotu nienależnie opłaconych składek liczone od dnia otrzymania od Prezesa Kasy Rolniczego Ubezpieczenia Społecznego zawiadomienia o kwocie nienależnie opłaconych składek.

6 Podobnie jak ustawa o systemie ubezpieczeń społecznych, która w zakresie składek odsyła do odpowiedniego stosowania wielu przepisów Ordynacji podatkowej; do Ordynacji odsyła również ustawa o ubezpieczeniu społecznym rolników - w art. 51 ust. 1 pkt 1. 
6.

Reasumując: o ile stanowisko sądu I instancji (Sądu Okręgowego w Lublinie) było błędne, o tyle orzeczenie Sądu Apelacyjnego w Lublinie zasługuje na pełną aprobatę.

\section{Bibliografia:}

Łabanowski M. [w:] J. Wantoch-Rekowski (red.), Ustawa o systemie ubezpieczeń społecznych. Komentarz, Toruń-Warszawa 2007.

Wantoch-Rekowski J., Składki na ubezpieczenie emerytalne. Konstrukcja i charakter prawny, Toruń 2005. 